\title{
Fishing the marine food web along the Indian coast
}

\author{
E. Vivekanandan*, M. Srinath, Somy Kuriakose \\ Central Marine Fisheries Research Institute, Kochi 682018, India
}

Received 5 July 2004; received in revised form 11 October 2004; accepted 19 October 2004

\begin{abstract}
The annual mean trophic level (TrL) of marine fish landings along the Indian coast consisting of 53 exploited species/groups was estimated for the period 1950-2002. The landings as well as TrL increased along the northwest (NW) and southwest (SW) coasts. However, increase in the landings was associated with decrease in mean $\operatorname{TrL}$ along the east coast, particularly along the southeast (SE) coast at the rate of 0.04 per decade. The increasing trend of the FIB index ceased in the last 5-10 years along three coasts. A backward-bending signature in the landings versus TrL plot for the SE coast in the last 6 years indicates fisheries-induced changes in the ecosystem owing to low productivity of the coastal waters and high density of fishing craft. The landings of most of the large predators increased along the Indian coast, but higher removals appear to have helped proliferation of their prey, the mid-level carnivores. Fishing the food web has been influenced by environmental fluctuations, advanced fishing technologies, and market-driven, deliberate fishing on low-trophic level (TL) invertebrates such as the penaeid prawns.
\end{abstract}

(c) 2004 Elsevier B.V. All rights reserved.

Keywords: Landings; Trophic level; FIB index; Fishing the food web; Indian coast

\section{Introduction}

Assessment of exploited stocks has hitherto been carried out using the classical single species-based models. These models generally take into account the relationship of yield (or catch rate) with the fishing effort or relationship of yield with the population and

\footnotetext{
* Corresponding author. Present address: Madras Research Centre of Central Marine Fisheries Research Institute (CMFRI), 75 Santhome High Road, Chennai 600028, India. Tel.: +91 44 24617317; fax: +914424617290.

E-mail address: evivekanandan@hotmail.com (E. Vivekanandan).
}

other fishery related parameters. As a rule these models ignore the biological interactions, the effect of environment and the effect of fishing on the ecosystem. The ecosystem consideration of effect of fishing is gaining importance and has become a thrust area of investigation in assessment of exploited stocks. It is increasingly realized now that changes in ecosystems could be due to ecological and exploitation parameters either singly or in combination, and hence, the assessment of stocks need to be tuned accordingly (Caddy and Garibaldi, 2000). Pauly et al. (1998) examined the FAO capture fisheries production database for 1950-1994 in terms of trophic levels of the catch and showed that landings from global fisheries have 
shifted from large piscivorous fishes toward small invertebrates and planktivorous fishes, a process now called "fishing down marine food webs". They estimated that the trophic levels of fisheries landings declined at a rate of about 0.1 per decade. One concern about this trend is that fishing may cause large and valuable predatory fish to be replaced by other species lower down the food web. This may not only affect the value of fisheries, but may cause significant problems in the structure and function of marine ecosystems (FAO, 2001).

The gradual decline in the mean trophic level of fish landings is significant in the Eastern North and Central Atlantic, Southeast Pacific, Mediterranean Sea, and Black Sea (Caddy and Garibaldi, 2000). In the tropical belt, this trend is not very marked but does occur, as evidenced in the Gulf of Thailand (Christensen, 1998). Along the Indian coast, there has been an unprecedented expansion of fishing fleets in the last half century and the fish landings has increased by more than five times (Devaraj and Vivekanandan, 1999; Srinath, 2003). However, it is not known whether the increase in the landings has been achieved by fishing down the food web. In the present paper, the trend in fishing the marine food web along the Indian coast during 1950-2002 has been analysed. Since further expansion of fleet and application of new fishing technologies have to be done more carefully than in the past, the analysis is expected to help plan strategies for realizing better productivity from the food web occurring in the Indian seas.

\section{Material and methods}

For the analysis, two data sets were used. The first data set on the trophic levels (TL) for 707 species of fish, crustaceans and cephalopods covering 53 commercially exploited species/groups along the Indian coast was obtained from Vivekanandan et al. (in press). The mean trophic level of the exploited groups is given in Table 1.

The second set comprises data on the fish landings in four coastal zones, viz., northwest (NW), southwest (SW), northeast (NE), and southeast (SE) along the Indian coast (Fig. 1) for the years from 1950 to 2002, which was collected and published annually by Central Marine Fisheries Research Institute, Kochi, India. The zonation is based on the dominance of fish groups in the
Table 1

Trophic level (TL) of commercially important fish groups/species along the Indian coast (after Vivekanandan et al., in press)

\begin{tabular}{|c|c|c|}
\hline Group/species & Number of species & Mean TL \\
\hline \multicolumn{3}{|c|}{ Herbivores and Detritivores (TL: $2.00-2.50$ ) } \\
\hline Hilsa & 1 & 2.00 \\
\hline Mullets & 11 & 2.42 \\
\hline Oil sardine & 1 & 2.50 \\
\hline \multicolumn{3}{|l|}{ Omnivores (TL: 2.51-3.00) } \\
\hline Penaeid prawns & 29 & 2.51 \\
\hline Non-penaeid prawns & 3 & 2.51 \\
\hline Crabs & 9 & 2.70 \\
\hline Other shads & 11 & 2.98 \\
\hline Stomatopods & 5 & 3.00 \\
\hline \multicolumn{3}{|c|}{ Mid-level carnivores (TL: 3.01-3.50) } \\
\hline Lesser sardines & 11 & 3.15 \\
\hline Silverbellies & 12 & 3.17 \\
\hline Whitebaits & 8 & 3.20 \\
\hline Whitefish & 1 & 3.20 \\
\hline Flying fishes & 2 & 3.20 \\
\hline Pomfrets & 2 & 3.20 \\
\hline Other perches & 114 & 3.20 \\
\hline Lobsters & 6 & 3.20 \\
\hline Other clupeids & 6 & 3.27 \\
\hline Setipinna & 2 & 3.30 \\
\hline Unicorn cod & 1 & 3.30 \\
\hline Octopus & 6 & 3.30 \\
\hline Miscellaneous & 73 & 3.33 \\
\hline Coilia & 4 & 3.35 \\
\hline Soles & 18 & 3.39 \\
\hline Thryssa & 11 & 3.40 \\
\hline Indian mackerels & 2 & 3.40 \\
\hline Flounders & 10 & 3.42 \\
\hline Catfishes & 14 & 3.44 \\
\hline Sciaenids & 32 & 3.50 \\
\hline Cuttlefishes & 6 & 3.50 \\
\hline \multicolumn{3}{|c|}{ High-level carnivores (TL: 3.51-4.00) } \\
\hline Threadfin breams & 14 & 3.53 \\
\hline Goatfishes & 5 & 3.54 \\
\hline Threadfins & 7 & 3.55 \\
\hline Rays & 28 & 3.58 \\
\hline Halfbeak and fullbeaks & 6 & 3.60 \\
\hline Pigface breams & 14 & 3.61 \\
\hline Bombayduck & 1 & 3.70 \\
\hline Squids & 6 & 3.70 \\
\hline Scads & 9 & 3.76 \\
\hline Eels & 9 & 3.84 \\
\hline Snappers & 60 & 3.88 \\
\hline Rockcods & 18 & 3.90 \\
\hline Sharks & 42 & 4.00 \\
\hline \multicolumn{3}{|l|}{ Top predators (TL: >4.01) } \\
\hline Other carangids & 35 & 4.07 \\
\hline Leatherjackets & 4 & 4.15 \\
\hline Ribbonfishes & 6 & 4.20 \\
\hline Lizardfishes & 4 & 4.30 \\
\hline Wolf herrings & 2 & 4.35 \\
\hline Horse mackerel & 1 & 4.40 \\
\hline Indian halibut & 1 & 4.40 \\
\hline Barracudas & 4 & 4.40 \\
\hline Seerfishes & 5 & 4.40 \\
\hline Tunas & 9 & 4.40 \\
\hline Billfishes & 6 & 4.52 \\
\hline
\end{tabular}




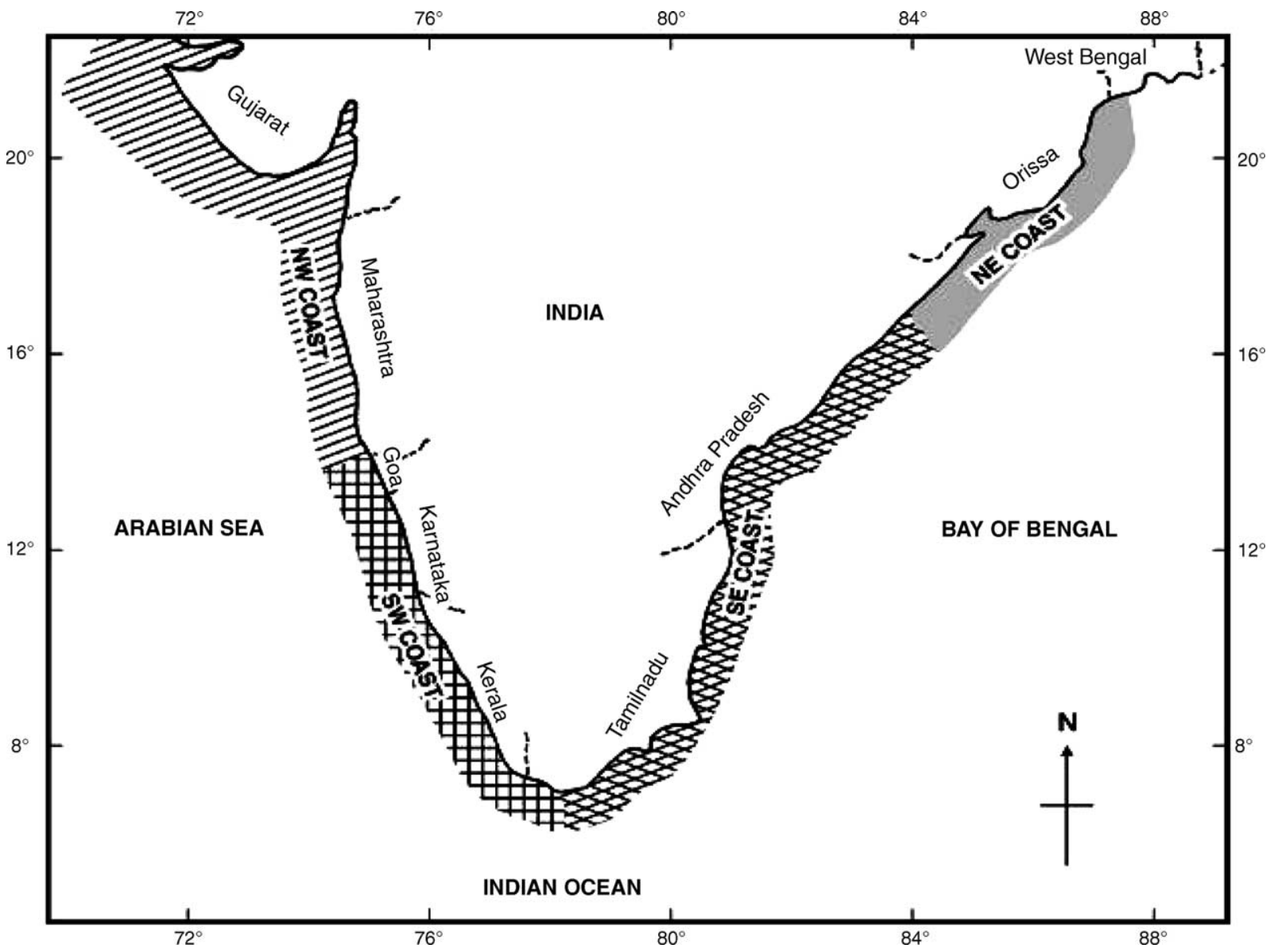

Fig. 1. Four coastal zones along the Indian coast; the maritime states are also indicaled.

landings. For instance, the most dominant groups in the landings during 1981-2002 along the NW coast were the bombayduck, sciaenids, and non-penaeid prawns, whereas along the SW coast, the oil sardine, Indian mackerel, and carangids were dominant (Table 2). Only 2 groups, namely the penaeid prawns and cephalopods were common in the list of top 10 groups in the NW and SW coasts, and 4 groups were common among the NE and SE coasts. On the other hand, eight groups were common among the NW and NE coasts, indicating the latitudinal similarity in distribution of fish stocks.

To understand the trend in fishing the marine food web, the two data sets were analysed as follows:

(i) The mean trophic level $\left(\operatorname{TrL}_{i}\right)$ for a given year $i$ was estimated by multiplying the landings $\left(Y_{i}\right)$ by the trophic levels of the individual species/groups $j$, then taking a weighted mean (Pauly et al., 1998), that is,

$\operatorname{TrL}_{i}=\frac{\sum_{i j} \mathrm{TL}_{j} Y_{i j}}{\sum Y_{i j}}$

where $\mathrm{TL}_{j}$ is the trophic level of individual species/group $j, Y_{i j}$ the landings of that species/group, $\Sigma_{i j}$ the summation of all values of $\left(\mathrm{TL}_{j} \times Y_{i j}\right)$, and $\Sigma Y_{i j}$ is the total landings of all species/groups. The decline, if any, in the $\operatorname{TrL}_{i}$ over the years is considered as "fishing down the marine food web".

(ii) The observed trends were interpreted by plotting the $\operatorname{TrL}_{i}$ against landings. This interpretation facilitated analysis of the relationship between the landings and fishing the food web. 
Table 2

Landings (\% of total landings of respective coast) of top 10 groups in each coastal zone (based on annual average landings during 1981-2002)

\begin{tabular}{|c|c|c|c|c|c|c|c|c|c|c|}
\hline & NW coast & & SW coast & & NE coast & & SE coast & & All four coasts & \\
\hline 1 & Bombayduck & 12.8 & Oil sardine & 20.0 & Sciaenids & 15.3 & Lesser sardines & 11.1 & Oil sardine & 8.6 \\
\hline 2 & Sciaenids & 11.1 & Indian mackerel & 13.0 & Hilsa shad & 12.0 & Silverbellies & 9.7 & Penaeid prawns & 7.9 \\
\hline 3 & Non-penaeid prawns & 9.4 & Carangids & 9.1 & Bombayduck & 8.0 & Oil sardine & 7.2 & Indian mackerel & 6.6 \\
\hline 4 & Penaeid prawns & 9.4 & Penaeid prawns & 8.0 & Catfish & 8.0 & Penaeid prawns & 6.6 & Sciaenids & 6.4 \\
\hline 5 & Ribbonfishes & 8.3 & Whitebaits & 5.7 & Pomfrets & 5.3 & Indian mackerel & 5.3 & Carangids & 5.1 \\
\hline 6 & Cephalopods & 4.3 & Threadfin breams & 5.4 & Ribbonfishes & 5.2 & Carangids & 4.6 & Bombayduck & 5.0 \\
\hline 7 & Catfishes & 3.5 & Stomatopods & 5.2 & Penaeid prawns & 5.0 & Sciaenids & 4.1 & Ribbonfishes & 4.8 \\
\hline 8 & Coilia & 3.4 & Cephalopods & 3.9 & Non-penaeid prawns & 4.2 & Whitebaits & 4.1 & Non-penaeid prawns & 4.4 \\
\hline 9 & Pomfrets & 3.0 & Soles & 3.3 & Lesser sardines & 3.9 & Ribbonfishes & 3.0 & Lesser sardines & 4.2 \\
\hline 10 & Sharks & 2.8 & Lesser sardines & 3.0 & Coilia & 2.5 & Rays & 2.6 & Cephalopods & 3.3 \\
\hline Total & & 69.7 & & 77.6 & & 69.4 & & 58.3 & & 56.3 \\
\hline
\end{tabular}

(iii) The exploited fishery groups were categorized into three groups: trophic category $1(\operatorname{TrC} 1)$ consisting of herbivores, detritivores and omnivores (TL: 2.00-3.00); trophic category $2(\operatorname{TrC} 2)$ consisting of mid-level carnivores (TL: 3.01-3.50) and trophic category $3(\operatorname{TrC} 3)$ consisting of high-level carnivores and top predators (TL: > 3.51). The contribution of each category to the total landings was determined. This analysis is considered useful for monitoring ecosystem change. Declines in the percentage of higher categories can be a result of fishing down marine food webs (Caddy and Garibaldi, 2000).

(iv) A fair evaluation of the impacts of a fishery should not be based on an index such as the mean TrL, which simply declines as the fishery moves down the food web (Pauly et al., 2000). Rather, it should be based on an index that should decline only when catches do not increase as expected. An index developed by Pauly et al. (2000), which indicated whether a fishery is balanced (FIB) in ecological term or not, was used for the present analysis. The FIB index for any year $i$ in a series is defined by:

$$
\begin{aligned}
\mathrm{FIB}= & \log \left(Y_{i} \times\left(\frac{1}{\mathrm{TE}}\right)^{\mathrm{TrL}_{i}}\right) \\
& -\log \left(Y_{0} \times\left(\frac{1}{\mathrm{TE}}\right)^{\mathrm{TrL}_{0}}\right)
\end{aligned}
$$

where $Y$ is the landings, TE the transfer efficiency (the fraction of production passing from one TL to the next higher TL), TrL the mean trophic level in the catch, and 0 refers to any year used as a baseline. TE was considered as 0.1 following Pauly and Christensen (1995). In the equation given above, the TE for production has been applied for the landings.

This analysis did not consider the discards. The bottom trawlers discard low-value juveniles for which proper estimates are not available. Kurup et al. (2003) estimated the discard along the Kerala coast (southern part of the SW coast) as about $15 \%$ of the trawl catch in 2001 and 2002. The discard comprised of carnivores (TL: <3.55) such as the threadfin breams, goatfishes, sciaenids, cephalopods, crabs, and non-penaeid prawns. Had all those caught were included for the analysis, one should expect fishing down the food web to have been more visible than the one shown here. However, the magnitude of the effect of discard on the catch versus mean $\operatorname{TrL}$ signature could not be evaluated without data on the species/group composition in the discard along the entire Indian coast.

\section{Results}

\subsection{NW coast}

The landings along the NW coast increased considerably from 0.45 million tones (mt) in 1975 to $1.05 \mathrm{mt}$ in 2000 (Fig. 2a). The mean TrL, which was between 3.05 and 3.30 in the 1950s, increased after the development of the fisheries and remained between 3.35 and 3.42 in the 1980s and 1990s. The mean TrL was higher (3.39) in the 1990s than in the 1950s (3.18). 
a. Landings and mean trophic level
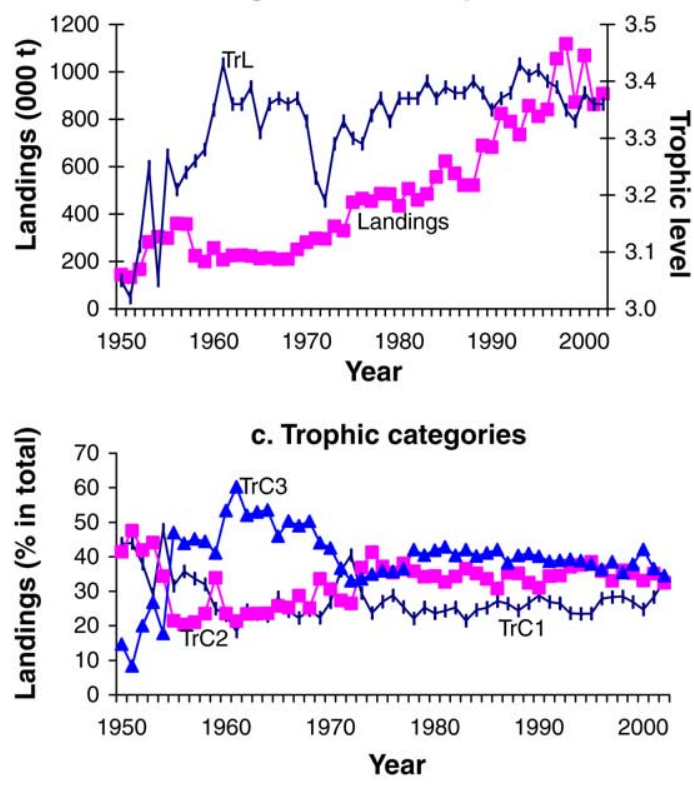

b. Plot of mean trophic level against landings

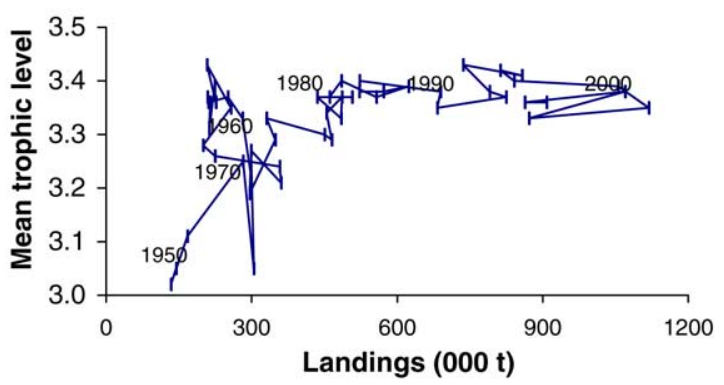

d. FIB index

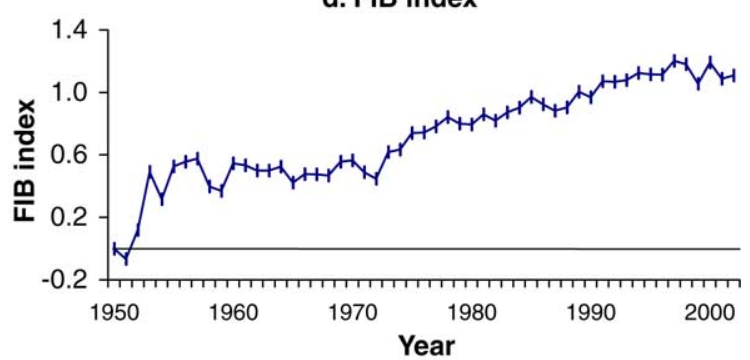

Fig. 2. Trends in parameters related to fishing the food web along the northwest coast.

The substantial increase in the landings during 1990-2000 was achieved with the TrL remaining almost stable (Fig. 2b). A notable feature of the NW coast is the higher contribution of the $\operatorname{TrC} 3$ (high-level carnivores and top predators) than that of $\operatorname{TrC} 2$ and $\operatorname{TrC} 1$ to the total landings (Fig. 2c). Along the NW coast, the landings of the following top predators (TrL: >4.0) increased substantially: sharks, lizardfishes, rockcods, ribbonfishes, horse mackerel, seerfishes, tunas, barracudas (since 1991), and Indian halibut (increased during 1989-1994, but declined thereafter). Evidently, the top predators are being targeted in the later years with improved fishing capabilities.

A continuous upward trend in the FIB was observed through the five decades, and especially after 1972 (Fig. 2d) indicating the development of the fishery. Among the four zones, the FIB index was highest for the NW coast, remaining above 1.0 for 14 years between 1989 and 2002.

\subsection{SW coast}

Along the SW coast, where fisheries was well developed much before that of the NW coast, the landings increased from $0.25 \mathrm{mt}$ in 1950 to $0.91 \mathrm{mt}$ in 1990, but remained almost stagnant at around $0.78 \mathrm{mt}$ in the last 12 years (Fig. 3a). Among the four coastal zones, (a) the lowest annual TrL (2.75 in 1964), (b) the lowest mean TrL (3.14) during 1950-2002, and (c) the maximum fluctuation in the annual TrL (CV: $5.4 \%)$ was along the SW coast.

The plot of mean TrL against the landings along the SW coast had a signature marked by abrupt phase shifts (Fig. 3b). The SW coast is a classical example of upwelling-driven fisheries, where the fisheries are harvested largely by phyto-and-zooplanktivores (such as the oil sardine, lesser sardines, and Indian mackerel), responding by major fluctuations in biomass to changes in primary productivity associated with upwelling nutrients. The contribution of $\operatorname{TrC} 1$ and $\operatorname{TrC} 2$ was high for most of the years, indicating the dominance of fish groups in low-trophic categories (Fig. 3c). However, the percentage of $\operatorname{TrC} 3$ increased in the 1990s. Among the top predators (TrL: >4.0), the landings of ribbonfishes and barracudas increased since the mid 1980s. However, the landings of other top predators such as the seerfishes and tunas, which were high during 1985-2000, sharply declined in 2001 and 2002, and that of the sharks continuously decreased since 1989 . 
a. Landings and mean trophic level

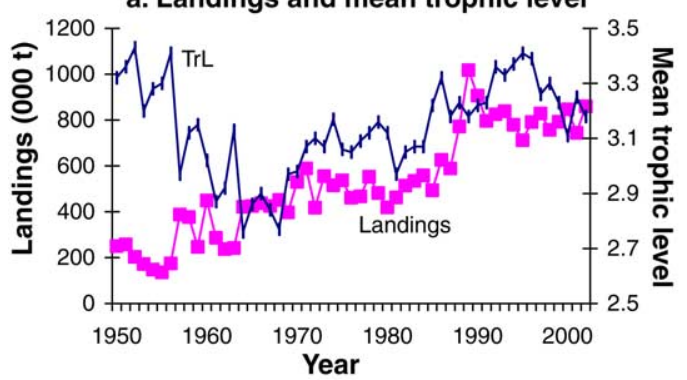

c. Trophic categories

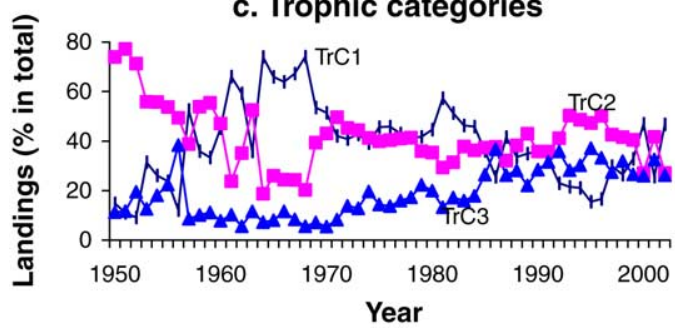

b. Plot of mean trophic level against landings

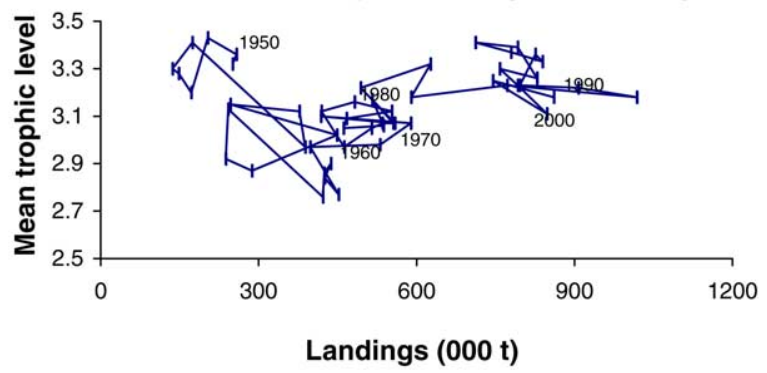

d. FIB index

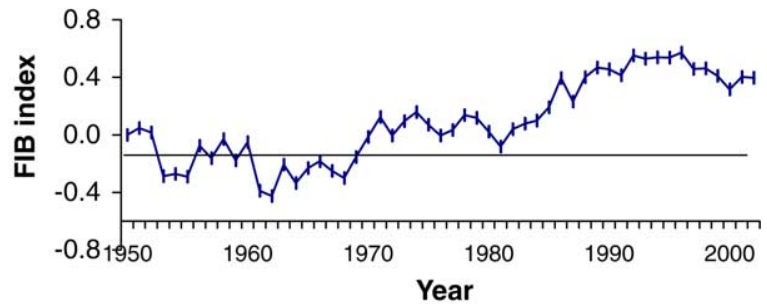

Fig. 3. Trends in parameters related to fishing the food web along the southwest coast.

The landings of penaeid prawns (TrL: 2.5), crabs (TrL: 2.7), and stomatopods (TrL: 3.0 ) increased since the mid 1980s, but that of the cephalopods (TrL: 3.5) decreased during 1998-2002.
The FIB index was below zero for several years until 1970 , increased in the 1980s, and was high $(>0.410)$ in the 1990s (Fig. 3d). The highest FIB was only 0.572 (1996).

\section{a. Landings and mean trophic level}

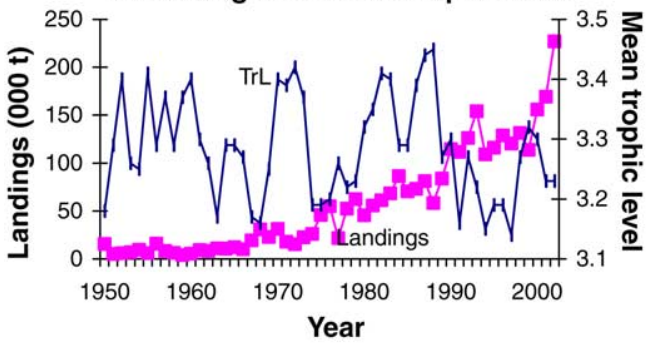

c. Trophic categories

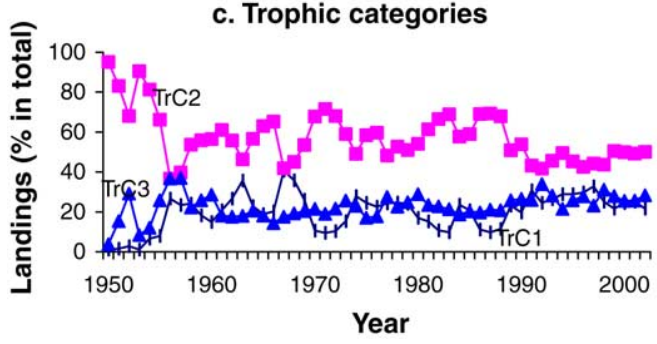

\section{b. Plot of mean trophic level against landings}

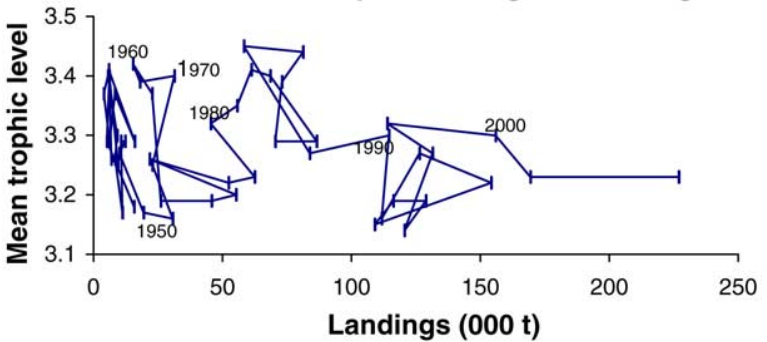

d. FIB index

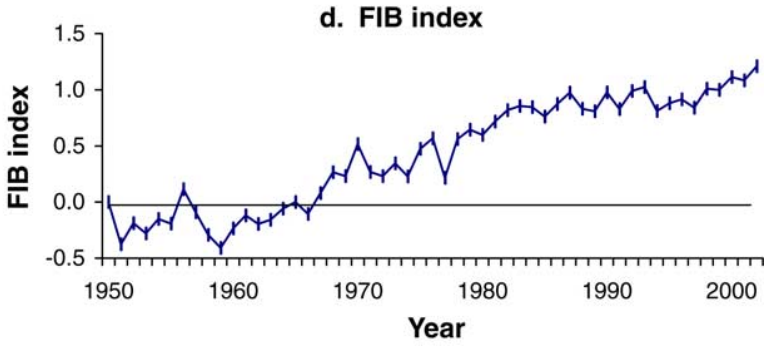

Fig. 4. Trends in parameters related to fishing the food web along the northeast coast. 


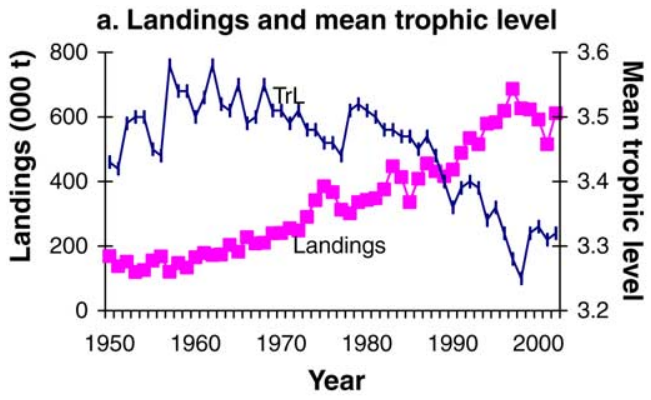

c. Trophic categories

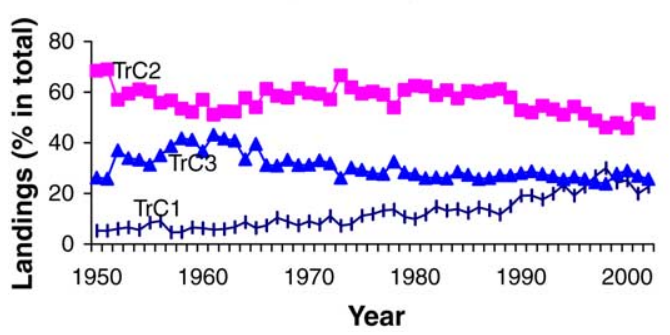

b. Plot of mean trophic level against landings

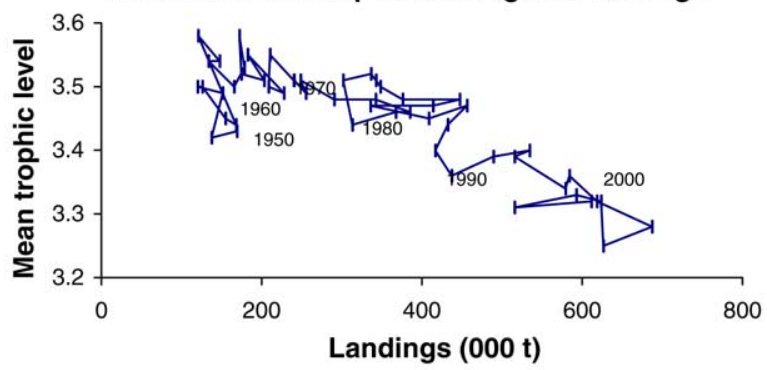

d. FIB index

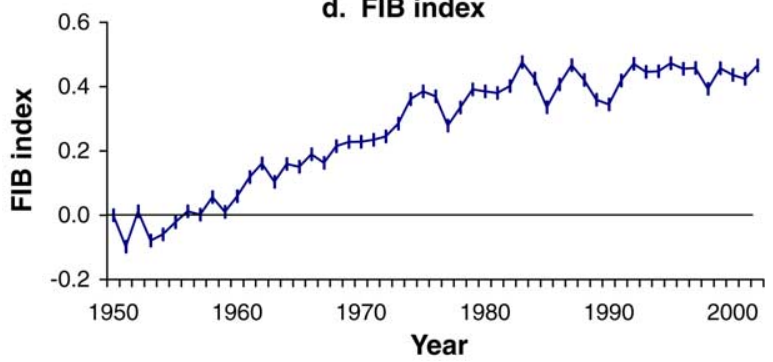

Fig. 5. Trends in parameters related to fishing the food web along the southeast coast of India.

\subsection{NE coast}

In the early years (1950-1965), when the landings were very low, the TrL fluctuated widely (Fig. 4a). In the later years (1988-1997), considerable increase in the landings was associated with steep decline in the TrL from 1989 to 1997. The mean TrL was lower in the 1990s (3.22) compared with that in the 1950s (3.30). Since the early 1980s, the plot of mean TrL against the landings had the signature of a declining trend in the mean $\mathrm{TrL}$ with increasing landings (Fig. 4b).

The percentage of $\operatorname{TrC} 2$ was high in all the years (Fig. 4c). However, the contribution of $\operatorname{TrC} 2$ decreased in the last 12 years, and $\operatorname{TrC} 1$ gradually replaced $\operatorname{TrC} 2$. The landings of the lesser sardines, Hilsa shad, Coilia, Setipinna and Thryssa, sciaenids, cephalopods, and penaeid and non-penaeid prawns increased in the 1990s. Among the large predators, the landings of bombayduck, ribbonfishes, and horse mackerel increased. The FIB index was below zero during most of the years until the mid 1960s. However, the FIB showed an upward trend in the later years and reached 1.2 in 2002 (Fig. 4d).

\subsection{SE coast}

The landings along the SE coast increased from $0.17 \mathrm{mt}$ in 1950 to $0.61 \mathrm{mt}$ in 2002 (Fig. 5a). However, the TrL decreased from 3.58 in 1958 to 3.32 in 2002. Among the four coastal zones, the mean TrL was found to decrease conspicuously along the SE coast, indicating a gradual transition in landings from piscivorous predators toward planktivorous pelagic fish and invertebrates.

The plot of mean TrL against the landings clearly indicated that the landings increased by exploiting fishes in low-trophic level i.e., by fishing down the food web (Fig. 5b). In the last 6 years (1997-2002), the tendency of the signature to bend backwards indicates that increase in the landings may not be possible any more despite decline in the TrL. The contribution of $\operatorname{TrC} 3$, which was $41.7 \%$ to the total landings in 1958, gradually decreased to $25.7 \%$ in 2002 (Fig. 5c), and the contribution of $\operatorname{TrC} 1$ increased from 4.8 to $22.6 \%$ during the corresponding period. However, it is interesting to note that the landings of fishes higher in the TrL did not decrease during 1950-2002. The landings of the top predators, viz., the lizardfishes, rockcods, horse 


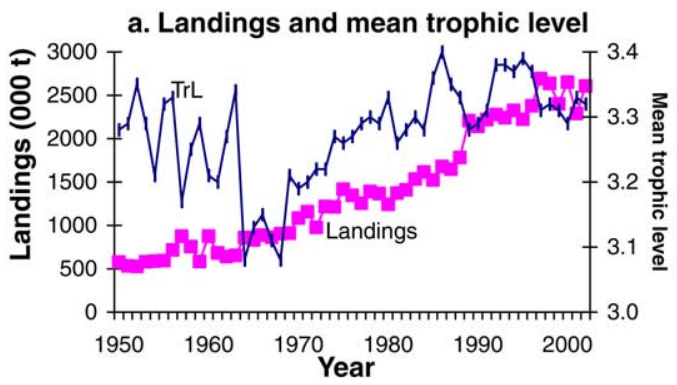

b. Plot of mean trophic level against landings

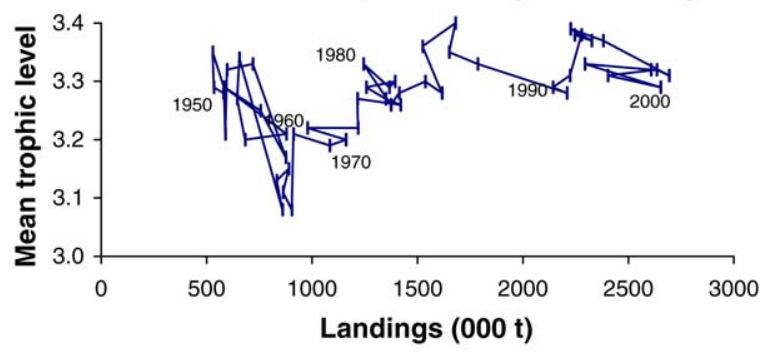

c. Trophic categories

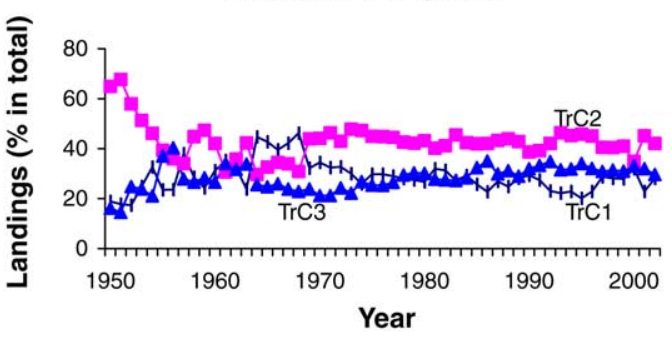

d. FIB index

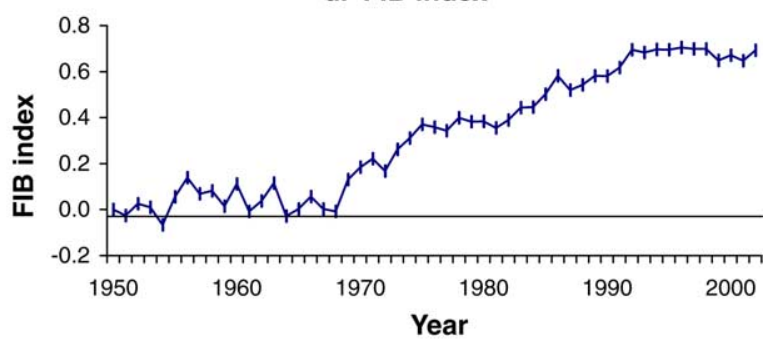

Fig. 6. Trends in parameters related to fishing the food web along the Indian coast.

mackerel, seerfishes, and barracudas increased in the 1990s. In the last two decades, the landings of other predators such as the sharks, ribbonfishes, tunas, and Indian halibut did not increase, but did not decrease either. One of the major changes in the fisheries along the SE coast is the incursion of the oil sardine (TL: 2.5). The oil sardine, which did not contribute substantially to the fishery during 1950-1988 (annual landings: $0-4533 \mathrm{t}$ ), suddenly emerged as a major fishery in 1989 (21,331 t), and since then, continued to increase in the landings, reached 111,540 $\mathrm{t}$ in 1997, but decreased to $33,202 \mathrm{t}$ in 2002. The oil sardine landings contributed $5.1,16.2$, and $5.4 \%$ to the total landings along the SE coast in 1989, 1997, and 2002, respectively. The emergence of a fishery for the oil sardine has reduced the mean $\operatorname{TrL}$ of the fishery rather than the decline in the landings of large predatory fishes. In addition to the oil sardine, the landings of other groups with low-TrL such as the penaeid prawns consistently increased in the last two decades, and that of the lesser sardines, crabs and cephalopods in the 1990s.

The FIB index increased during the time series, peaked at 0.476 in 1983, and did not increase thereafter (Fig. 5d).

\subsection{All four coastal zones}

The marine fish landings along the Indian coast increased from $0.5 \mathrm{mt}$ in 1950 to $2.6 \mathrm{mt}$ in 2002 (Fig. 6a). The landings showed the following three trends: (i) gradual increase from $0.5 \mathrm{mt}$ in 1950 to $1.1 \mathrm{mt}$ in 1970; (ii) accelerated increase in the $1970 \mathrm{~s}$ and $1980 \mathrm{~s}(2.1 \mathrm{mt}$ in 1989) and (iii) decline in the annual rate of production in the 1990s (2.6 $\mathrm{mt}$ in 2002).

The mean annual TrL of the exploited stocks showed the following trends: (i) wide fluctuations in the 1950s and 1960s, but a general decrease from 3.28 in 1950 to the lowest of 3.07 in 1968; (ii) increase from 3.07 in 1968 to 3.37 in 1992 and (iii) decrease from 3.37 in 1992 to 3.31 in 2002 . In the first two decades and in the last decade, the mean $\operatorname{TrL}$ decreased with increase in the landings, but in the 1970s and 1980s, the mean TrL increased along with the landings. A dip in the mean TrL occurred during 1964-1968 because of large catches of the oil sardine (annual average landings: $0.27 \mathrm{mt}$ compared to $0.11 \mathrm{mt}$ during 1960-1963) along the SW coast. The SW coast, which experiences upwelling during southwest monsoon, replenishes plankton population and supports plankton feeding small pelagics such 
as the oil sardine. During 1964-1968, the oil sardine landings along the SW coast alone contributed $31 \%$ to the total marine landings along the Indian coast.

The signature of the plot of TrL against the landings for the Indian coast was vertically fluctuating during 1950-1970 with less horizontal extension compared to 1985-2002 (Fig. 6b). The signature indicates that (i) when the landings did not considerably increase during 1950-1970, the TrL fluctuated widely; (ii) the increase in the landings during 1971-1985 was due to exploitation of demersal mid-level carnivorous fishes (TrL: 3.01-3.50) by the bottom trawlers and (iii) the increase in the landings during 1986-2002 was due to a top-down response of the TrL from 1986 to 1990 and from 1993 to 2002.

The contribution $\operatorname{TrC} 3$ increased from $21.2 \%$ in 1970 to $32.0 \%$ in 2000 (Fig. 6c). On the other hand, the contribution of $\operatorname{TrC} 1$ decreased from 34.5 to $22.9 \%$ during the corresponding period.

The FIB index, which was low for the Indian coast during 1950-1968, showed an upward trend until 1992 (Fig. 6d) owing to increases of both the landings and mean TrL, suggesting that the fishery was expanding for nearly 25 years (from 1969 to 1992) to stocks previously not, or only lightly exploited. After 1992, the catches increased, but the TrL decreased, thereby arresting the upward trend in the FIB.

\section{Discussion}

One of the arguments against use of mean trophic level of the catch and/or FIB as reliable indicators of fisheries impacts is that the food web model is not static, but is variable along time, and due to diet switching and variable prey preferences (McCann et al., 1998;
Kondoh, 2003). It is possible that variability in food web model may also be due to fisheries impacts, but this needs to be validated. Nevertheless, this analysis provides a good picture of the components of the ecosystem targeted by the fishery.

Among the four coastal zones, the SW coast experiences upwelling during southwest monsoon and is rich in productivity. The NW coast has the largest inshore $\left(<50 \mathrm{~m}\right.$ depth) area $\left(90,000 \mathrm{~km}^{2}\right)$ and maximum number of mechanized vessels $(23,618)$ (Table 3$)$. The intensity of mechanized vessels $\left(0.39\right.$ boat $\left./ \mathrm{km}^{2}\right)$ and catch $\left(31.6 \mathrm{t} / \mathrm{km}^{2}\right)$ are highest along the SW coast. The number of mechanized and motorized (boats with outboard motor) boats increased in all the coastal zones during 1961-1998. However, the number of nonmotorized (traditional) boats decreased except along the NE coast. The increase in fishing activity could be discerned from the increase in the number of mechanized boats by 7.4 times along the Indian coast.

The analysis of the TrL and FIB values revealed distinct differences between the coastal zones (Table 4). Due to the predominance and fluctuations of small pelagics in the fishery, the SW coast remains as a distinct entity with the lowest mean trophic value (3.14), but with the highest CV (5.14\%). The mean TrL was highest (3.45) along the SE coast with lowest CV $(2.30 \%)$. The CV of FIB indicates more variations compared to the variations in $\operatorname{TrL}$, which reflects relative variation in the landings.

The decadal trend of TrL indicates that the mean TrL has decreased along the SE coast, from 3.53 during 1953-1962 to 3.32 during 1993-2002, i.e. at the rate of 0.04 per decade. There was marginal reduction along the NE coast too, but for the increase during 1983-1992. The correlation analysis of TrL, FIB with the total catch and catches of $\operatorname{TrC} 1, \operatorname{TrC} 2$ and $\operatorname{TrC} 3$

Table 3

Fisheries profile of four coastal zones in the Indian mainland

\begin{tabular}{|c|c|c|c|c|c|c|c|c|c|c|}
\hline \multirow[t]{3}{*}{ Coastal zone } & \multirow[t]{3}{*}{ Length (km) } & \multirow{3}{*}{$\begin{array}{l}\text { Area upto } 50 \mathrm{~m} \text { depth } \\
\left(\times 10^{3} \mathrm{~km}^{2}\right)\end{array}$} & \multicolumn{6}{|c|}{ Number of craft $/ \mathrm{km}^{2}$} & \multicolumn{2}{|c|}{ Landings $\left(\mathrm{t} / \mathrm{km}^{2}\right)$} \\
\hline & & & \multicolumn{2}{|c|}{ Mechanized } & \multicolumn{2}{|c|}{ Motorized } & \multicolumn{2}{|c|}{ Non-motorized } & \multirow[t]{2}{*}{1961} & \multirow[t]{2}{*}{1998} \\
\hline & & & 1961 & 1998 & 1961 & 1998 & 1961 & 1998 & & \\
\hline Northwest & 2347 & 90 & 0.04 & 0.26 & 0.00 & 0.06 & 0.12 & 0.08 & 2.3 & 12.4 \\
\hline Southwest & 994 & 24 & 0.08 & 0.39 & 0.00 & 0.74 & 1.21 & 0.71 & 12.0 & 31.6 \\
\hline Northeast & 640 & 27 & 0.002 & 0.23 & 0.00 & 0.15 & 0.13 & 0.28 & 0.3 & 4.9 \\
\hline Southeast & 2020 & 40 & 0.03 & 0.25 & 0.00 & 0.6 & 1.23 & 1.11 & 4.5 & 12.2 \\
\hline All 4 zones & 6001 & 181 & 0.04 & 0.27 & 0.00 & 0.28 & 0.51 & 0.42 & 3.8 & 14.6 \\
\hline
\end{tabular}


Table 4

Decadal changes in mean TrL and FIB values

\begin{tabular}{|c|c|c|c|c|c|c|c|c|}
\hline \multirow[t]{2}{*}{ Period } & \multicolumn{2}{|c|}{ NW coast } & \multicolumn{2}{|c|}{ SW coast } & \multicolumn{2}{|c|}{ NE coast } & \multicolumn{2}{|c|}{ SE coast } \\
\hline & TrL & FIB & $\operatorname{TrL}$ & FIB & $\operatorname{TrL}$ & FIB & TrL & FIB \\
\hline 1953-1962 & 3.27 & 0.48 & 3.12 & -0.22 & 3.32 & -0.18 & 3.52 & 0.03 \\
\hline 1963-1972 & 3.33 & 0.49 & 2.94 & -0.16 & 3.28 & 0.13 & 3.51 & 0.19 \\
\hline 1973-1982 & 3.34 & 0.76 & 3.09 & 0.06 & 3.27 & 0.52 & 3.48 & 0.36 \\
\hline 1983-1992 & 3.38 & 0.96 & 3.21 & 0.33 & 3.33 & 0.87 & 3.43 & 0.41 \\
\hline 1993-2002 & 3.38 & 1.13 & 3.28 & 0.46 & 3.22 & 0.99 & 3.32 & 0.45 \\
\hline Mean & 3.32 & 0.72 & 3.14 & 0.09 & 3.29 & 0.43 & 3.45 & 0.27 \\
\hline $\mathrm{CV}(\%)$ & 2.80 & 43.10 & 5.40 & 312.70 & 2.60 & 113.40 & 2.30 & 66.00 \\
\hline
\end{tabular}

indicates that the increased landings are associated with lowering of TrL along the east coast, but increased landings are positively correlated with mean $\operatorname{TrL}$ along the west coast (Table 5).

Table 5

Corrleation analysis of TrL and FIB with total catch and catch of each $\operatorname{TrC}$

\begin{tabular}{|c|c|c|c|c|c|c|}
\hline & Catch & $\operatorname{TrL}$ & FIB & $\operatorname{TrC} 1$ & $\operatorname{TrC} 2$ & $\mathrm{TrC} 3$ \\
\hline \multicolumn{7}{|l|}{ NW coast } \\
\hline Catch & 1.000 & & & & & \\
\hline TrL & 0.481 & 1.000 & & & & \\
\hline FIB & 0.921 & 0.741 & 1.000 & & & \\
\hline $\operatorname{TrC} 1$ & 0.964 & 0.288 & 0.824 & 1.000 & & \\
\hline $\operatorname{TrC} 2$ & 0.983 & 0.449 & 0.897 & 0.934 & 1.000 & \\
\hline $\operatorname{TrC} 3$ & 0.976 & 0.614 & 0.951 & 0.903 & 0.936 & 1.000 \\
\hline \multicolumn{7}{|l|}{ SW coast } \\
\hline Catch & 1.000 & & & & & \\
\hline $\operatorname{TrL}$ & 0.229 & 1.000 & & & & \\
\hline FIB & 0.873 & 0.647 & 1.000 & & & \\
\hline $\operatorname{TrC} 1$ & 0.642 & -0.533 & 0.232 & 1.000 & & \\
\hline $\operatorname{TrC} 2$ & 0.868 & 0.524 & 0.925 & 0.243 & 1.000 & \\
\hline $\operatorname{TrC} 3$ & 0.886 & 0.560 & 0.937 & 0.297 & 0.831 & 1.000 \\
\hline \multicolumn{7}{|l|}{ NE coast } \\
\hline Catch & 1.000 & & & & & \\
\hline $\operatorname{TrL}$ & -0.271 & 1.000 & & & & \\
\hline FIB & 0.889 & -0.094 & 1.000 & & & \\
\hline $\operatorname{TrC} 1$ & 0.956 & -0.462 & 0.793 & 1.000 & & \\
\hline $\operatorname{TrC} 2$ & 0.979 & -0.160 & 0.920 & 0.886 & 1.000 & \\
\hline $\operatorname{TrC} 3$ & 0.984 & -0.253 & 0.844 & 0.948 & 0.942 & 1.000 \\
\hline \multicolumn{7}{|l|}{ SE coast } \\
\hline Catch & 1.000 & & & & & \\
\hline $\operatorname{TrL}$ & -0.836 & 1.000 & & & & \\
\hline FIB & 0.894 & -0.541 & 1.000 & & & \\
\hline $\operatorname{TrC} 1$ & 0.949 & -0.901 & 0.732 & 1.000 & & \\
\hline $\mathrm{TrC} 2$ & 0.977 & -0.768 & 0.936 & 0.868 & 1.000 & \\
\hline $\operatorname{TrC} 3$ & 0.983 & -0.787 & 0.896 & 0.929 & 0.945 & 1.000 \\
\hline
\end{tabular}

The difference in the decadal trend of the fishery between the coastal zones is due to the innate differences in the productivity between the coastal zones. The Arabian Sea in the west coast of India is one of the most productive regions in the world oceans. Due to several physical and chemical processes, the surface chlorophyll a in the Arabian Sea $\left(0.32-1.12 \mathrm{mg} / \mathrm{m}^{3}\right)$ is four to five times greater compared to the Bay of Bengal in the east coast $\left(0.06-0.28 \mathrm{mg} / \mathrm{m}^{3}\right.$ ) (Prasanna Kumar et al., 2002). Whereas upwelling enhances the productivity and abundance of planktivores along the SW coast, sinking process during winter substantially increases the productivity of detritus and abundance of demersals along the NW coast (Banse and McClain, 1986; Bhattathiri et al., 1996). The biomass of benthic organisms in the northernmost part of the Arabian Sea is very high $\left(38.5 \mathrm{~g} / \mathrm{m}^{2}\right)$ compared to the mean biomass of Bay of Bengal $\left(5.3 \mathrm{~g} / \mathrm{m}^{2}\right)$ (Parulekar et al., 1982). Because of high productivity and resilience, the landings along the west coast have increased without reduction in the mean TrL.

Fishing the food web could be influenced by the impacts of advancement of fishing technologies, and changes in market-driven exploitation (Caddy and Garibaldi, 2000; Stergiou, 2002). When the fishery was in early stages of development in India during 1950-1965, the largest single-species fishery, viz., the gillnet-based oil sardine fishery along the SW coast influenced not only the total marine landings along the entire Indian coast, but the mean TrL as well. The oil sardine Sardinella longiceps is primarily a phytoplanktivore with low-TL (2.50). The fishery is driven by upwelling and other environmental variabilities, and rarely shows stability (Devaraj et al., 1997). 
For instance, the oil sardine catch along the SW coast increased from $7412 \mathrm{t}$ (1.0\% of the total marine landings in India) in 1956 to $191,469 \mathrm{t}$ (21.9\%) in the very next year. In correspondence with the low oil sardine landings, the mean TrL of the total marine landings along the Indian coast was higher at 3.33 in 1956, and with increase in the landings in 1957, the mean TrL decreased to 3.17. Thus, the oil sardine fishery was chiefly responsible for the mean $\operatorname{TrL}$ when the fishery was underdeveloped. The major technological advancements that occurred almost simultaneously along the entire Indian coast changed the situation in the later years. Introduction of bottom trawlers in the 1960s, high-opening trawlnet and synthetic gear materials in the 1970s, ringseines and minitrawls in the 1980s, motorization of artisanal craft in the mid 1980s, and spread of the trawl fleets from core inshore fishing grounds $(<50 \mathrm{~m}$ depth) to relatively under exploited deeper areas (>100 m depth) from the early 1990s are some of the technological advancements responsible for the increase in the marine fish landings during the five decades (Devaraj and Vivekanandan, 1999). From the late 1990s, the bottom trawlers have further extended the fishing grounds up to $400 \mathrm{~m}$ depth in pursuit of deepsea prawns (Rajan et al., 2001). In the 2000s, when the fishery is fully developed, the oil sardine landings along the Indian coast touched an all time record of $364,860 \mathrm{t}(13.8 \%$ of the total landings and $50 \%$ increase from the earlier year), but the mean $\operatorname{TrL}$ decreased only marginally (from 3.31 in 1999 to 3.29 in 2000). Thus, the importance of oil sardine in influencing the mean TrL considerably reduced due to the induction of several resource groups with higher TL into the fishery.

From the 1970s, the trawl fishery targeted the lowTL (2.51) penaeid prawns, which attracted export market. The contribution of penaeid prawns to the total marine landings along the Indian coast increased from $4.8 \%$ in the 1950 s to $10.1 \%$ in the 2000 s, having a share in pulling down the mean TrL. This market-driven fishery for the penaeid prawns is a deliberate choice of fishing down the food web. The FIB index, which enables an assessment whether the fishery is balanced in ecological terms or not, should decline when catches do not increase as expected (Pauly et al., 2000). Owing to increase of both catches and mean TrL, the FIB index increased until the mid 1990s along the NW and SW coasts, and until 1982 along the SE coast, but subsequently declined. The arrest in the upward trend in the
FIB index for the last 20 years along the SE coast is due to alarming increase in the fishing fleet strength. The number of mechanized vessels increased by more than eight times along the SE coast during 1961-1998, which is higher than the increase along the NW and SW coasts (Table 3 ). Assuming that fisheries along the SE coast tend to switch from species with high-TL to species with low-TL in response to changes of their relative abundance, the backward-bending signature in the catch versus TrL curve in the last 6 years may be due to fisheries-induced changes in the food webs of the ecosystem. Due to high fishing intensity vis-à-vis low productivity, the fisheries is unable to sustain the mean TrL along the SE coast. It appears that the catch may decline along with the already declining TrL along the SE coast in the next decades.

\section{References}

Banse, K., McClain, C.R., 1986. Winter blooms of phytoplankton in the Arabian Sea as observed by the coastal zone color scanner. Mar. Ecol. Progr. Ser. 34, 201-211.

Bhattathiri, P.M.A., Pant, A., Sawant, S., Gauns, M., Matondkar, S.G.P., Mohanraju, R., 1996. Phytoplankton production and chlorophyll distribution in the eastern and central Arabian Sea in 1994-1995. Curr. Sci. 71, 857-862.

Caddy, J.F., Garibaldi, L., 2000. Apparent changes in the trophic composition of world marine harvests: the perspective from the FAO capture database. Ocean Coastal Manage. 43, 615-655.

Christensen, V., 1998. Fishery-induced changes in a marine ecosystem: insight from models of the Gulf of Thailand. J. Fish Biol. 53, 128-142.

Devaraj, M., Kurup, K.N., Pillai, N.G.K., Balan, K., Vivekanandan, E., Sathiadhas, R., 1997. Status, Prospects and Management of Small Pelagic Fisheries in India, vol. 31, RAP Publications, FAO, Rome, pp. 91-198.

Devaraj, M., Vivekanandan, E., 1999. Marine fisheries of India: challenges and opportunities. Curr. Sci. 76, 315-332.

FAO, 2001. The State of World Fisheries and Aquaculture. FAO, Rome, 173 pp.

Kondoh, M., 2003. Foraging adaptation and the relationship between food-web complexity and stability. Science 299, 1388-1391.

Kurup, B.M., Premlal, P., Thomas, J.V., Anand, V., 2003. Bottom trawl discards along Kerala coast: a case study. J. Mar. Biol. Ass. India 45, 99-107.

McCann, K., Hastings, A., Huxel, G., 1998. Weak trophic interactions and the balance of nature. Nature 395, 794-798.

Parulekar, A.H., Harkantra, S.N., Ansari, A.A., 1982. Benthic production and assessment of demersal fishery resources of the Indian Seas. Indian J. Mar. Sci. 11, 107-114.

Pauly, D., Christensen, V., 1995. Primary production required to sustain global fisheries. Nature 374, 255-257. 
Pauly, D., Christensen, V., Dalsgaard, J., Froese, R., Torres Jr., F., 1998. Fishing down marine food webs. Science 279, 860-863.

Pauly, D., Christensen, V., Walters, C., 2000. Ecopath, ecosim, and ecospace as tools for evaluating ecosystem impact of fisheries. ICES J. Mar. Sci. 57, 697-706.

Prasanna Kumar, S., Muraleedharan, P.M., Prasad, T.G., Gauns, M., Ramaiah, N., de Souza, S.N., Sardesai, S., Madhupratap, M., 2002. Why is the Bay of Bengal less productive during summer monsoon compared to the Arabian Sea? J. Geophys. Res. 29, 88/1-88/4.

Rajan, K.N., Nandakumar, G., Chellappan, K., 2001. Innovative exploitation of deepsea crustaceans along the Kerala coast. Mar. Fish. Inf. Serv. 168, 1-11.
Srinath, M., 2003. An appraisal of the exploited marine fishery resources of India. In: Mohan Joseph, M., Jayaprakash, A.A. (Eds.), Status of Exploited Marine Fishery Resources of India. Central Marine Fisheries Research Institute, Kochi, India, pp. 117.

Stergiou, K.I., 2002. Overfishing, tropicalization of fish stocks, uncertainty and ecosystem management: resharpening Ockham's razor. Fish. Res. 55, 1-9.

Vivekanandan, E., Meiyappan, M.M., Gomathy, S., Thirumilu, P., Balakumar, S.K. Trophic level of fishes occurring along the Indian coast. Naga, in press. 